\title{
Children and Young People's Participation Rights: Looking Backwards and Moving Forwards
}

\author{
Christina McMellon \\ TRIUMPH network based at MRC/Cso Social and Public Health Sciences \\ Unit, University of Glasgow, Glasgow, Scotland \\ Christina.McMellon@glasgow.ac.uk \\ E. Kay M. Tisdall \\ Moray House School of Education and Sport, University of Edinburgh; \\ Childhood \& Youth Studies Research Group, Edinburgh, Scotland \\ k.tisdall@ed.ac.uk
}

\begin{abstract}
Children and young people's participation is an ever-growing demand. Thirty years on from the UN Convention on the Rights of the Child's adoption, however, fundamental challenges continue for participation that are widely recognised cross-nationally but remain stubbornly consistent. As a way in to considering the children and young people's participation literature more generally, all articles referring to participation in their titles were identified from The International Journal of Children's Rights. These ${ }^{6}$ articles were analysed to identify trends, challenges and opportunities. The analysis found: a remarkably consistent narrative on participation over the 30 years; limitations on domains considered, geography and conceptual clarity; and far more written about challenges than solutions. Drawing on these findings and considering the participation literature more generally, the article recommends that the field expands its geographic and intellectual boundaries, uses powerful concepts like agency, competency and autonomy with greater precision, and explores fresh ideas like child protoganism, activism and children as human rights defenders.
\end{abstract}

\section{Keywords}

children - childhood - young people - youth - participation - activism - activists children's rights 
The United Nations Convention on the Rights of the Child (UNCRC) has been a catalyst for promoting children and young people's participation rights. Adopted by the UN General Assembly in November 1989, the UNCRC details a number of Articles grouped together as participation rights, which were novel in their articulation and their application to children and young people. ${ }^{1}$ With States Parties charged with implementing the UNCRC, and currently the USA being the only UN member state having not ratified it, jurisdictions around the world have changed policy and legislation to recognise children and young people's individual and collective rights to participate. The UNCRC has inspired civil society and a range of organisations - from the private to the public sector - to develop participation activities with children and young people, for various goals of empowerment, influence and involvement (Pereznieto et al., 2011; Birnbaum and Saini, 2012; Gal and Duramy, 2015). While all too often children and young people are unaware of their participation rights under the UNCRC, they themselves have taken action on such issues as gun control, antiwar and climate change. ${ }^{2}$ Children and young people's participation has thus received growing attention since the UNCRC's adoption in 1989 .

With this attention have come accumulated concerns from within the participation field about actualising these rights. Concerns have been largely practical, in terms of the challenges faced within activities and by children and young people when they participate. Challenges range from concerns about tokenism and lack of impact on decision making, when children and young people do participate, to the lack of sustainability of participation activities (see below). The academic field has raised conceptual concerns, such as the lack of theoretical underpinning and development of the literature and research, which in turn limits the more fundamental questions and opportunities to help develop practice (Tisdall et al., 2014). Children and young people's participation thus faces both practical and conceptual challenges, 30 years on from UNCRC adoption.

1 This article generally uses the phrase "children and young people", following young people's typical preference to be referred to as the latter in the UK. Broadly, "children and young people" in this journal article refers to people up to the age of 18 , following Article 1 within the United Nations Convention on the Rights of the Child.

2 For example, see https://www.nytimes.com/2018/o3/14/us/school-walkout.html (28 May 2019), https://www.bbc.co.uk/news/av/uk-politics-47257547/children-protest-over-climate -change-and-environment (28 May 2019), https://www.theguardian.com/world/2013/feb/15/ iraq-war-mass-protest (28 May 2019). 
This article seeks to learn from the children and young people's participation field over the last 30 years, to assess trends, challenges and opportunities. The field has grown immensely and there is an extensive literature, from "grey" literature available through organisations and the internet, to practice advice found in newsletters, practitioners' publications and teaching modules, to extensive research and academic publications in journals and books. For example, a topic search of children and participation, in a leading database, the Web of Science Core Collection, resulted in 23,143 articles in English alone. ${ }^{3}$ This article reviews the contents of The International Journal of Children's Rights (IJCR) in the context of trends and development in the wider children and young people's participation literature, drawing on the methodological approach of McNamee and Seymour (2013). From IJCR's first issue in 1993, to 2019, 56 articles have been published with variations of participation in their titles: these were used as the basis for the article's analysis. The following sections review key aspects of participation rights within the UNCRC, then present the methodology used to identify and assess the articles, before proceeding to the findings and conclusion.

\section{Taking Forward Participation Rights in the UNCRC}

The UNCRC has a range of rights that are categorised as "participation rights". These include Article 13 (freedom of expression), Article 14 (freedom of thought, conscience and religion), Article 15 (freedom of association and peaceful assembly) and Article 17 (access to information). Article 12 has been identified as a general principle of the UNCRC (UN Committee on the Rights of the Child, 2003) and is much cited. Article 12's precise wording is:

1. States Parties shall assure to the child who is capable of forming his or her own views the right to express those views freely in all matters affecting the child, the views of the child being given due weight in accordance with the age and maturity of the child.

2. For this purpose, the child shall in particular be provided the opportunity to be heard in any judicial and administrative proceedings affecting the child, either directly, or through a representative or an appropriate body, in a manner consistent with the procedural rules of national law.

3 The search was undertaken on 30 August 2019 with the following (TS=(children AND participation)) AND LANGUAGE: (English) AND DOCUMENT TYPES: (Article).

Indexes=SCI-EXPANDED, SSCI, A\&HCI, CPCI-S, CPCI-SSH, BKCI-S, BKCI-SSH, ESCI, CCREXPANDED, IC Timespan=All years. 
The UNCRC itself does not use the word "participation" in this Article. Its use is explained by the UN Committee on the Rights of the Child in its General Comment on Article 12:

This term has evolved and is now widely used to describe ongoing processes, which include information-sharing and dialogue between children and adults based on mutual respect, and in which children can learn how their views and those of adults are taken into account and shape the outcome of such processes (2009:3).

Implicitly, the General Comment is addressing a number of the challenges faced in implementing children and young people's participation rights. Across both individual and collective decision making, adults' concerns about children and young people's best interests and protection (which are also rights recognised in the UNCRC) can squeeze out children and young people's rights to participate (Ruiz-Casares et al., 2017). Adult (and sometimes children and young people's) ascriptions of children and young people's capacities and competencies can exclude them from being involved in decision making (Moran-Ellis and Tisdall, 2019). Adult attitudes and systems more generally do not always include and adapt to children and young people, so that children and young people's views are excluded or not given due weight (Gal and Duramy, 2015). In collective decision making, children, young people and adults criticise participation activities as often tokenistic, lacking impact on decision making and failing to give timely feedback to children and young people on decisions made and reasons thereof (Percy-Smith and Thomas, 2010; Lundy, 2019). Despite the popularity of children and young people's participation within the children's rights field, children and young people very often face considerable challenges to having their participation rights recognised and realised.

To forward children and young people's participation rights, various models have been developed that address children and young people's collective participation. An early typology was the "ladder of participation" developed by Hart (1992). Hart's ladder has eight rungs, with the bottom three categorised as non-participation (manipulation, decoration and tokenism). The higher rungs depict varying degrees of participation, from the fourth rung of "assigned and informed" up to the eighth rung of "child-initiated, shared decisions with adults". This ladder has proven highly popular, is frequently cited in the literature and is used in training and development to catalyse groups and individuals to consider how children and young people are involved in decision making. Possibly because of this extensive use, it has been subject to certain criticisms. 
For example, the image of the ladder suggests that the goal is to be at the highest rung, signaling 'child-initiated and shared decisions with adults' is the ideal form of participation (Sinclair, 2004). However, for certain types of decisions that involve multiple stakeholders - such as legislative changes that affect numerous groups - it may be that another rung is appropriate, such as "adultinitiated, shared decisions with children". To dissolve this apparent hierarchy, Treseder (1997) placed the categories around a circle. Further, he did not include the bottom three categories, which are not considered participation.

Both the ladder and the circle retain certain problems. For example, they separate children and adults in two groups, which reifies the distinction between adulthood and childhood, and does not recognise the diversity across, and potential power relationships within, children and adult groups. Neither diagram emphasises contextual matters, such as socio-economic, political, cultural or organisational factors, which can dramatically impact on children and young people's participation. Ignoring such matters can lead to the criticisms of children and young people's participation generally, as being culturally inappropriate (Valentin and Meiner, 2009) and failing to effect decision making (see above). The diagrams fail to incorporate changes over time and for those involved: for example, at certain times within the "lifetime" of that particular process, participation may be child-initiated whereas at others it may be adult-initiated. The diagrams thus do not assist fully with key issues for children and young people's participation, in terms of power, the diversity of children and adults, and changes over time.

Other models have been presented that seek to do so. Shier's model for organisations was published in 2001, emphasising what organisations need to do in order to realise children and young people's participation. It addresses certain issues that can block participation, such as ethos, organisational structures and practice. He has further developed participation models, drawing on work with children in Nicaragua, that emphasise children's own learning processes and development into community leaders (Shier, 2015). In 2011, Johnson published her Change-Scape model, that brings in the wider contextual issues and changes over time, to the processes of children and young people's participation as supported by organisations (for an updated discussion on this model, see Johnson, 2017). A model gaining widespread interest has been developed by Lundy. Drawing on an intensive analysis of Article 12 within the full requirements for children's human rights, the model has four components:

SPACE: Children must be given safe, inclusive opportunities to form and express their view.

VOICE: Children must be facilitated to express their view. 
AUDIENCE: The view must be listened to.

INFLUENCE: The view must be acted upon, as appropriate.

Department of Children and Youth Affairs Ireland, 2015: 21

Lundy's model was originally developed to address the limitations of how student "voice" was being considered in education literature and practice (2007) and continues to develop in order to address the challenges of children and young people's participation. At the timing of writing, she and colleagues are doing further work on the component of "influence", as this remains one of the most difficult areas for participation. These models are drawing attention to the components required for meaningful and effective participation.

The models are largely addressing children and young people's participation as a group, in such arenas as influencing communities, services or policies. The academic literature now contains numerous examples of such collective participation at local, national and international levels (e.g. Pereznieto, 2011; Bandyopadhyay, 2015; World Vision, 2017). Contributions come from numerous fields, from children and young people's social media (e.g. Livingstone, 2014), children as consumers (e.g. Cook, 2013), children's geographies and international development (e.g. von Benzon and van Blerk, 2017), to children as workers and child labour (e.g. Liebel and Invernizzi, 2018), to early years (e.g. Pascal and Bertram, 2009). There is considerable interest in children and young people's participation in research, in the social sciences broadly but also extending into health and other fields (e.g. Larsson et al., 2018). Published literature also considers particular groups of children and young people, who may risk being excluded by participation, such as disabled children and very young children (Theobold et al., 2011). Further, there is research and commentary about children and young people's participation as individuals, from informal involvement in families, peer groups and communities (e.g. Dunst et al., 2002) to more formal systems like courts and criminal justice, social work, schooling (e.g. Birnbaum and Saini, 2012; van Bijleveld et al., 2015). There is no shortage now of literature on children and young people's participation.

Yet, within all this literature, the familiar challenges are often found. It is thus fruitful to look back over the past 30 years, to identify trends, challenges and opportunities.

\section{$3 \quad$ Methodology}

This paper both looks back over the key issues in the field of children and young people's participation from the last 30 years and celebrates the contribution 
TABLE 1 Original articles with participat* in the text, 1993-2019 The International Journal of Children's Rights

Time frame Number of articles

\begin{tabular}{lr}
\hline 2016 to date & 89 \\
2011 to 2015 & 142 \\
2006 to 2010 & 112 \\
2000 to 2005 & 84 \\
1993 to 1999 & 98 \\
\hline Total & 525 \\
\hline
\end{tabular}

made to this field by the IJCR as the leading children's rights journal. We (the authors) sought to identify articles that were focused on children and young people's participation within the IJCR archives. We first searched for articles with variations of participation anywhere in the article (participat*). The Heinonline database allowed for all of the journal's issues to be searched in this way, from 1993 to 2019. This resulted in 634 articles (as of 3 May 2019). We then excluded editorials and book reviews, so as to look for original articles. This resulted in 525 articles, which are distributed across the years as in Table 1.

This substantial number of articles is a finding in itself but an initial review demonstrated that children and young people's participation was mentioned without developed consideration in a large number of these journal articles.

In order to concentrate on articles that substantially addressed children and young people's participation, we sought to identify articles through keywords and abstracts. This presumed that, if participation (or its variations) were used in these sections, the author was signalling a focus on children and young people's participation within the article. However, we were unable to locate databases, which facilitated searches across all of the journal's issues from 1993 to 2019. No combination of databases allowed for this full time-span to be searched, for either keywords or the abstract. After consulting early issues, abstracts were not published for articles. We found abstracts that had been added subsequent to publication, for some articles, but not the earliest articles.

We thus returned to the Heinonline database, which allowed us to search for variations of participat* in the article's title. Again, we are assuming that the author is signalling the importance of children and young people's participation, by including it in the title. This resulted in 56 articles, distributed across the journal years as detailed in Table 2: 
TABLE 2 Original articles with participat* in the title, 1993-2019

The International Journal of Children's Rights

Time frame Number of articles

\begin{tabular}{lr}
2016 to date & 10 \\
2011 to 2015 & 10 \\
2006 to 2010 & 26 \\
2000 to 2005 & 8 \\
1993 to 1999 & 2 \\
\hline Total & 56 \\
\hline
\end{tabular}

We undertook an initial review to check whether articles did have a substantial focus on children and young people's participation, and this was confirmed. We thus used these 56 articles as our core dataset and subsequent analysis was undertaken on the full articles.

We initially read a selection of articles in different year groupings, to develop a coding frame. We identified descriptive elements (e.g. the article's geographical focus, whether the article was based on empirical research and if so what kind, children's ages) and thematic elements (e.g. how participation was discussed, how children were discussed, identified positives, challenges and solutions). We both did this initially and separately, compared codings, and produced an excel framework to then go through each article. This became the core basis for the article's discussion below, which was largely analysed through thematic analysis (Braun and Clarke, 2006) with some descriptive quantitative analysis. In the findings' discussion below, for a "typical" finding we provide up to three references as examples, although there will be substantially more articles that could be referred to.

We draw readers' attention to two matters. First, some codes are more subjective than others. For example, most articles do not self-classify themselves in terms of their country contexts, their disciplinary backgrounds or their policy fields. As a result, the classification is dependent on our views and, further, some articles remain unclassified. Second, in 2008 , there was a special issue on children and young people's participation in public decision making. This had an explicitly cross-national and cross-disciplinary agenda, thus adding diversity by country and disciplines.

While we have undertaken our search, sample selection, and article identification systematically, we see this approach as a device to consider the field of children and young people's participation. The IJCR is leading in its field of 
children's human rights but, while interdisciplinary, it likely attracts more legal scholars than other childhood studies' journals and children's participation is likely to be presented as a rights issue. The IJCR publishes in English, so there will be trends in other languages (see below), which risk being missed. Other articles in the IJCR may focus on children and young people's participation but not include participat* in the title, and we will not have identified them. We note that the articles reviewed reflect the scope of writing on children and young people's participation within the IJCR and that they sit within a much wider literature related to children and young people's participation. Nonetheless, as a device, this approach has identified a rich range of articles and the analysis provides a number of provocative key findings, which we consider in light of the broader trends within the literature. Below, we discuss the descriptive and thematic findings under two headings: familiar tropes, and challenges and solutions.

\section{$4 \quad$ Findings: Looking Backwards and Moving Forward}

\subsection{Familiar Narrative and Familiar Tropes}

The most striking finding was how familiar the story was of children and young people's participation over the 30 years. Take, for example, two examples from articles published 15 years apart:

Alderson (2000) believes that the child's right to express a view is the most important participation right and Freeman (1996) describes Article 12 as the linchpin of the convention. Children themselves (Morrow, 1999; Taylor, Smith and Naim, 2001) give a high priority to participation rights. Yet Article 12 is also 'one of the most widely violated and disregarded in almost every sphere of children's lives' (Shier, 2001:108). (Smith, 2002: 74).

In the 25 years of the International Journal of Children's Rights, the importance of children's rights has been stressed, the need for children's participation and engagement has been asserted, and in moving through the next 25 years what is needed is an approach that enables children to speak for themselves in a manner that is more than seeking their views when being consulted. (Cassidy, 2017: 332).

These paragraphs are typical of the narrative, which contains at least three tropes. First, the UNCRC and, particularly Article 12, are asserted as especially important for children's rights, and are seen as radical, innovative and/or 
challenging conceptually and practically (e.g. Ochaita and Espinosa, 1997; Rap, 2016; Taylor, 2017). Second, participation rights are so radical, innovative or challenging because they confront "traditional" views of children (e.g. as vulnerable, dependent and incompetent) with alternative views of children as autonomous, competent social actors (e.g. Smith, 2002; Jones, 2017; Hester and Moore, 2018). Here, articles often relate to what might be considered "childhood studies" literature and the sociology of childhood that developed from the 1970s onwards in the Global North (see Mayall, 2012 for historical review). As powerfully put forward by Prout and James (1990), childhood should be considered a social construction and children have to be recognised as active in constructing their own lives, thus creating new understandings that are part of reconstructing childhood itself. In these ways, developments in childhood studies intersect and provide conceptual ballast to children and young people's participation rights (see Tisdall and Punch, 2012 for review). Third, the articles have a familiar concern about poor implementation. This is evident early on in articles published. For example, Parkinson's 2001 article states:

One of the most frequently cited principles of the United Nations Convention on the Rights of the Child is Article 12, which provides that a child shall be provided the opportunity to be heard in any judicial and administrative proceedings affecting him or her. Despite a quite widespread acceptance of this principle, it is perhaps easier to state than to apply (259).

This concern about the absence or inadequacy of implementation is often the premise of the articles, leading into their substantive discussions. In short, the narrative starts with mentioning the potential of the UNCRC and its participation rights, notes how these challenge traditional constructions of childhood and that, despite their potential, children and young people's participation rights are often not recognised or realised.

This narrative may be empirically correct (e.g. Kilkelly and Donnelly, 2011; Ensor and Reinke, 2014; Jones, 2017) but its consistency does not suggest the field is moving beyond this critique. Reasons could be the familiarity of the predominant focus and conceptual development. For example, most articles refer to a single country context, with few comparative (and even fewer comparing a substantial number of contexts). Further, the geographical spread of the articles is limited. The most common country context is the UK (whether as a whole or referring to a particular jurisdiction, 17 articles), followed by Australia (4), India (3), New Zealand (3) and South Africa (3). It is now a familiar comment that the childhood studies need to learn more from different parts of 
the world (Tisdall and Punch, 2012; Wells, 2015; Hanson et al., 2018), particularly as most children live in the Global South yet the Global North has dominated childhood studies. The participation field needs to ensure it considers and is challenged by developments in all parts of the world.

Considering the articles as a portfolio, their conceptual development is potentially limited in four ways. First, while not surprising given the traditions of academic publishing, no articles were explicitly authored by children and young people. Standpoint theory, for example in feminist or disability studies (Garland-Thomson, 2005), would suggest the benefits of children and young people asserting their own interpretations to develop conceptualisations and empirical research. Second, there is little collective development of related concepts or of the theory of participation as it relates to rights beyond the childhood studies' trope (described above). Given the critique by several authors of an over-reliance on typologies and the lack of theoretical developments (Thomas, 2007; Tisdall, 2015), we found more articles than we anticipated that are predominantly theoretical (we classified six as such). However, we found limited developments across the field building together conceptual ideas; authors or research teams were making insightful contributions but only within their own work. Thus the sociology of childhood remains the predominant conceptual work alluded to and this is usually not deeply interrogated nor developed itself. Third, the UNCRC is often used as a "stepping stone" for the journal articles, frequently mentioned in the first sentence or paragraph of the article. It is then often not expanded upon (although note exceptions such as Forde et al., 2016) and even fewer articles integrate discussions of the UNCRC and its articles into the substantive parts of the article and the conclusion. A few articles critique Article 12(1) for its limitations (e.g. Franklin and Sloper, 2005; Cassidy, 2017) but this is rare. Again, while there are exceptions (e.g. Rap, 2016; Cassidy, 2017), few articles relate children and young people's participation rights to other human rights treaties, remaining squarely within children's rights discussions. Thus the UNCRC and Article 12 are frequently used as devices to start off the journal article, but they are themselves not fundamentally scrutinised and developed in-depth or in the wider human rights' context. This combination of factors leads to little sustained interrogation of participation and participation rights themselves beyond the familiar list of challenges (see below). One last factor is the coverage of policy and practice contexts. Schooling and education are the most common contexts (12 articles), along with healthcare ( 7 articles). Of potential significance is what is missing or limited. For example, no article focuses on children's participation rights in business (beyond one on child labour, Invernizzi and Milne, 2002), despite the pervasiveness of business and consumerism within the lives of children and 
young people in the globalised world and the considerable childhood consumerism literature published elsewhere. There is limited attention to children's participation rights in a number of other arenas, also important to many children and young people, such as play, leisure and sports. Thus, there are gaps in considering children's participation rights in key domains that affect them (like business and sports) and in bringing in literatures to children's right studies predominantly found elsewhere (like consumerism, human geography, international development, early years and play).

A wide variety of words are used in the articles, alongside or instead of participation, such as views, autonomy, self-determination, wishes and opinions. They are rarely defined or differentiated (with a few exceptions, such as Struthers (2016) between voice and participation, and Taylor et al. (2007) between wishes and views). Terms like agency and competency are frequently interwoven in sentences but rarely defined or conceptualised. This lack of precision goes beyond academic niceties, with implications conceptually and practically. The use of "agency" in childhood studies, for example, has been roundly critiqued for assuming that children's agency is innately positive, thus making it problematic if in the particular circumstances children's agency seems questionable (Bordonaro and Payne, 2012; Edmonds, 2019) or circumscribed by their contexts (Klocker, 2007). Agency has been used as if it were something that children owned, rather than something expressed relationally (Esser et al., 2016; Gallagher, 2019). If the latter were accepted, the ramifications are practical as well as conceptual: leading to a consideration of "affordances" (Clarkin-Phillips and Carr, 2012), concentrating on how to support children's expressions of agency, and looking more critically about who defines and polices the norms of children's agency. Other terms clustered around participation in the field merit similar critique for what they contribute - and what they limit - both practically and conceptually (e.g. see Daly, 2018; Moran-Ellis and Tisdall, 2019; Mühlbacher and Sutterlüty, 2019).

In short, we were surprised in our analysis how familiar the narrative, tropes and coverage are over the 30 years. This suggests distinct opportunities to unsettle the participation field, in terms of greater conceptual precision, collective theoretical development, and addressing the lacunas in who and what are included in the discussions.

\subsection{Challenges and Solutions}

Articles very regularly identify the challenges of participation, which mirror the literature more generally (see Section 2 above). Far fewer solutions are offered, with the most hopeful offered from the Global South and/or learning from other fields. Below, we outline these challenges and solutions. 
The list of challenges for participation is lengthy, and we group them here in three ways. First, adults and adult systems poorly support children and young people's participation. One of the most common challenges discussed is the attitudes of some adults that detract from children and young people's participation: tensions between protection and participation rights including the belief that an adult's primary role is to protect children (e.g. Alderson et al., 2005; Tomanović-Mihajlović, 2000; Hester and Moore, 2018); perceived tensions between children and young people's and parents' rights (Kosher, 2018); a lack of understanding about, or belief in, the importance of children and young people's participation rights (e.g. Franklin and Sloper, 2005; Wyn, 2007; Forde et al, 2016). Adults are sometimes unwilling to address power dynamics and share power with children (e.g. Davis, 2007; Moses, 2008; Hester and Moore, 2018). This can be seen, for example, when adults use children's participation to support their own agendas (e.g. Invernizzi and Milne, 2002; LaFrancois, 2008; Taylor and Percy-Smith, 2008). Whilst most authors argue for a nuanced understanding of participation that challenges existing power structures in order to effect change, the practice of participation can often be tokenistic, decorative participation and not move beyond consultation (e.g. Wyness, 2001; Gallagher, 2008; Struthers, 2016). Thus adult attitudes, adult-child power dynamics and adult systems can diminish children and young people's participation opportunities.

Second, the articles add to the widespread concern that participation lacks impact (see Section 2), either not making a difference in decision making or a difficulty in knowing whether it does (e.g. Gallagher, 2008; Wheeler, 2010; Crowley, 2015). One practical reason is organisations' bureaucratic nature, which are not set up for children and young people's views to make a difference and where change occurs very slowly (e.g. Smith, 2007; Thomas, 2007; Fitzgerald et al., 2012). Further, Leviner (2018) writes about the challenge of how to involve children and young people's views in decision making alongside other people's views. Involving children and young people in decision making can be used to hide the need for more fundamental social change (e.g. Invernizzi and Milne, 2002; Davis, 2007; Thomas, 2007). Children and young people's participation tends to consider the local situation and yet many things affecting children and young people happen at the national and/or global scale (e.g. Cook, 2008; Hart, 2008). Thus, these concerns lead on from problematic adult attitudes, systems and power dynamics, but also point to additional issues about monitoring and feedback, how to bring children and young people together with other stakeholders, and scale.

Third, articles discuss the challenges related to which children and young people participate. One concern is that some young people (often older 
children and those from higher socio-economic backgrounds) are easier to involve than others and that, particularly when resources are limited, access to participation opportunities is not equal (e.g. Rampal, 2008; Gwandure and Mayekiso, 2011; Struthers, 2016). Several papers mention specific groups of children whose views are less likely to influence decision making: such as very young children (Hester and Moore, 2018), care experienced children (Winter, 2006), and children with communication difficulties (Franklin and Sloper, 2005). These exemplify widespread concerns more generally in the participation literature that certain groups risk being excluded from participation and efforts for particular methodological and practice development are required to ensure they are included. ${ }^{4}$ Several authors, writing in the contexts of education and residential care, find that children and young people can be overly pressured to participate or experience negative consequences should they not wish to participate (e.g. LaFrancois, 2008). Thus, some children and young people may be more likely to be invited to participate, creating inequities in access; if they refuse the invitation, though, they may experience negative repercussions.

Specific solutions offered by the papers reviewed are limited. Ideas of how to do this include: to draw attention to tokenism and manipulation (Wheeler, 2010); to raise awareness of participation rights (Vanner, 2014); to provide evidence of positive outcomes of participation (Franklin and Sloper, 2005); and to ensure adults understand the importance of building trusting relationships with the children they work with (Cook, 2008; Fitzgerald et al., 2012). These solutions are important but they are also perennial. Across the articles, however, two connected sets of ideas are promising to move through the "messy, fraught and ambiguous processes of children's participation" (Gallagher, 2008: 404).

Several papers illustrate that there is much that the Global North can learn from the Global South about viewing children and young people as important social contributors. For example, Butler (2008) describes how children and young people in Brazil - as political revolutionaries who have created and led social movements - utilise their own preferred means of communication (hiphop music, online networks) to share their views and campaign for change. Papers from different cultural contexts draw attention to both the cultural specificity of terms such as children, participation and community, and the importance of understanding children and young people's experiences and

4 For example, see special journal issues: "Valuing Disabled Children: Participation and Inclusion" Child Care in Practice 21(3) in 2015; "Children's perspectives and participation in research" European Early Childhood Education Research Journal 19(3) in 2011. 
understandings of their own lives and contexts (e.g. Gwandure and Myekiso, 2011). Invernizzi and Milne (2002) remind us that children's views might not fit with adults' received wisdom or ideas about appropriate participation, citing an example of children using social action to speak out on behalf of children who are working illegally rather than seeking to prevent the "problem" of child labour. The value of learning from these Global South contexts underlines the need to go beyond the limitations of the English-participation field, as discussed above.

Learning from outside the children and young people's participation rights field is also productive. There are active traditions of participation and community engagement that exist independently of the UNCRC. For example, the fields of liberation theology and popular education challenge social injustice through participants and educators working together to reflect upon the realities of their lives and taking action to affect positive change. In Brazil, where Paulo Freire originally advocated for popular education, Butler (2008) uses liberation theology to explain the example given above of children and young people being supported to develop and lead their own social movements addressing their own concerns. In the UK the field of community education has traditionally been informed by popular education, which seeks to raise awareness of the structural links between personal experiences and socio-political contexts. Taylor and Percy-Smith (2008) use a community development, rather than a children's rights perspective, to examine participatory spaces. They argue for a move away from only inviting children and young people into participatory spaces created by adults towards encouraging children and young people to self-organise in order to claim the spaces that they require. Community development approaches acknowledge children and young people as one diverse group of partners amongst others and advocate for the importance of creating structured opportunities for children, young people and adults to enter into dialogue about the issues that concern them (see also Davis, 2007). Learning from these different fields helps question assumptions, providing ideas about more "autonomous" opportunities and spaces for children and young people's participation, and more inter-related and intergenerational ones with other community members.

Reviewing these $5^{6}$ articles in the IJCR raises issues well-rehearsed in the participation field, reinforces some critiques, and provides some surprises. Together, this combination suggests opportunities for the field going forward. 
The list of challenges is depressingly familiar, even across typologies, domains and contexts. These challenges include concern about practice masquerading as children and young people's participation that would not make it to the third rung of Hart's ladder, and questions about what makes participation meaningful if its influence is in question. While the nuances of these challenges are continuously important to reflect upon, learn from, and to try and address, it does suggest that research needs to move beyond documention. The opportunity to investigate solutions seems more promising. Certain articles put forward examples that do seem to address some challenges, bringing out the potential for alternative ways of framing or undertaking children and young people's participation. While not excluding those developed in the Global North, some of the more provocative articles (at least for those in the Global North) were examples from the Global South. Similarly, while not wanting to exclude learning from within the field, examples and concepts from outwith children and young people's participation such as community development or popular education suggest alternative models conceptually and practically. Such new approaches offer opportunities to build upon our understanding of the socio-political aspects of participation that have sometimes been less examined in conceptual modelling of participation rights (although see Wyness, 2001; Wall and Dar, 2011). The participation field could move forward considerably by widening its boundaries and intersections - geographically, comparatively, inter-generationally and across disciplines.

This widening includes who is producing knowledge and particularly in developing collectively our ideas of children and young people's participation. We need to expand 'who counts' in at least two ways. We need to ensure we can learn from academics and others who are themselves located in and from the Global South, who can illuminate their own socio-cultural-political contexts and conceptual ideas (see Imoh et al., 2019). Academia and research, which have been bastions of adult power over knowledge, need to ensure children and young people's participation is not only the subject of such knowledge production but also part of the process of such knowledge production. Charles and Haines (2014), for example, recommend involving children and young people in conceptual discussions about participation. There are examples, ranging from co-production models in policy-making (e.g. Houghton, 2015) to participatory action research (e.g. McMellon and Mitchell, 2018), which merit further innovation and critical consideration (see also Cuevas-Parra and Tisdall, 2019; Tisdall, forthcoming). As such intense forms of children and young people's participation grow, so do questions about respecting their knowledge production and authorship in academic as well as other outputs. Journals are experimenting with specific spaces for children and young people to contribute 
(e.g. Canadian Journal of Children's Rights) and a small number of journal articles are appearing authored by, or co-authored with, children and young people (e.g. Meekison and Wan, 2018).

The review underlines a growing concern that the participation field uses influential concepts with more deliberate care. "Agency" has been subject to such scrutiny and learning from this is now percolating through the literature with practical implications. Other concepts - like competency, autonomy, empowerment and participation itself - merit similar scrutiny and careful use. As argued above, this is not simply an academic exercise, but reviewing the articles and reflecting on the research shows that imprecise use of these concepts is not helping and even detracting from children and young people's participation rights being mainstreamed, recognised and supported. Newer or underused phrases to the field may challenge this as well.

There is increasing recognition in the English literature of child protagonism, which is a well-considered term in Spanish and particularly in Latin America. The concept has particular advantages, as the concept recognises that children can instigate change and play an active role in their societies (see Liebel, 2007). Further, it links to ideas of active citizenship and participative democracy, which resonate in the history of many Latin American countries (see Rizzini, 2011; Nuggehalli, 2014; Larkins et al., 2015). Unpicking whether and how the concept can apply in contexts which do not support either active citizenship or democracy is needed, to see how widely the term can replace children's participation. In itself, its conceptualisations of children and childhood, and of change and power, provide opportunities to address the familiar challenges of children's participation.

Children as "human rights defenders" has rapidly gained international attention, propelled forward by the 2018 General Day of Discussion, "Protecting and empowering children as human rights defenders". Identifying children as human rights defenders brings them firmly within the wider human rights context, alongside adults, connected by the UN Declaration on Human Rights Defenders. Children and young people's participation has arguably stayed too long a specialist activity, outwith involvement of other groups in civic society to influence change. While this separation has some protective strengths, with children and young people's participation being separately funded or having particular access, it has weaknesses such as participation then being too easily side-lined or not capitalising on collective strength (see discussion in Tisdall et al., 2014). Not all of children and young people's participation individually or collectively is necessarily captured by the category of "human rights defenders" but its connections with the broader human rights discourse productively challenges "traditional" assumptions of childhood as inherently vulnerable 
and dependent to recognise children as important social actors (see discussion section 2). Further, the category brings together children and adults rather than separate groups (as Hart's ladder can do, see discussion section 2). The category of "human rights defenders" privileges the task of defending, rather than reifying and presuming a dichotomy between adults and children, adulthood and childhood.

Another opportunity is conceptualising children as activists or considering "child activism". Gwandure and Mayekiso (2011), for example, describe children as social activists who take on social change for themselves and each other. Activists do what they do because they believe it to be important and they choose the ways to do it that they think will be most effective, thus challenging the narrative that some ways to participate are more acceptable than others. Activists' focus may well include local issues, but it does not exclude national and international issues, as is evident with the current climate change protests by children and young people. Again, activism may not apply to all participation types and activities - but goes beyond some of the familiar challenges. The word activist is powerful, reflecting the need to challenge the power dynamics between children, young people and adults. Activists start conversations rather than relying upon adults to invite them in to existing ones; activists take up and take over spaces rather than waiting to be given them. Child activism, then, could provide a useful challenge and opportunity for the participation field (see Nolas et al., 2016 and Tisdall and Cuevas-Parra, 2019).

We were surprised at how consistent the paricipation narrative is, across 30 years, about the potential for children and young people's participation rights and their poor implementation. While this may be empirically accurate, it creates an imperative at least to have a new narrative, a new set of challenges, and some new conceptual and practical avenues in the next 30 years. Reviewing the IJCR articles in depth raised issues that are symptomatic of the children's participation field more generally (see Child Rights Now! (2019) for a similar evaluation from six international NGOs). It is time to widen our boundaries dramatically and in several different ways, for greater conceptual and theoretical precision and development, and to question the fundamentals of our knowledge production.

\section{Acknowledgements}

This article builds on a range of collaborative projects funded by the British Academy, Economic and Social Research Council/ UKRI (R451265206, 
RES-189-25-0174, RES-451-26-0685, ES/Too1399/1, ES/Soo4351/1) and Knowledge Exchange funds from the University of Edinburgh and the ESRC Impact Acceleration Account, the European Research Council, the European Union's Rights, Equality and Citizenship Programme (2014-2020), the Foundation of Canadian Studies, the Leverhulme Trust, the Royal Society of Edinburgh and the Social Sciences and Humanities Research Council of Canada and the partnership with World Vision International. We appreciate the detailed comments from an anonymous reviewer on the draft article.

\section{References}

Alderson, P., Hawthorne, J. and Killen, M., "The Participation Rights of Premature Babies", The International Journal of Children s Rights 2005 (13(1)), 31-50. DOI:10.1163/ 1571818054545231 .

Bandyopadhyay, D., How rural girls are standing up to child marriage in India. Girls not Brides 2015: http://www.girlsnotbrides.org/how-rural-girls-are-standing-up-to -child-marriage-in-india (12 November 2019).

Birnbaum, R. and Saini, M., "A scoping review of qualitative studies on the voice of the child in child custody disputes", Childhood 2012 (20(2)),260-282. DoI:10.1177/ 0907568212454148.

Bordonaro, L. and Payne, R.E.D., "Ambiguous Agency: Critical perspectives on social interventions with children and youth in Africa", Children's Geographies 2012 (10(4)), 365-372. DOI:10.1080/14733285.2012.726065.

Braun, V., and Clarke, V., "Using thematic analysis in psychology", Qualitative Research in Psychology 2006 (3(2)), 77-101. DoI:10.1191/1478088706qpo630a.

Butler, U.M., "Children's Participation in Brazil - A Brief Genealogy and Recent Innovations", The International Journal of Children's Rights 16(3) (2008): 301-312. DoI:10.116 3/157181808X311150.

Cassidy, C., "Philosophy with Children: A rights-based approach to deliberative participation", The International Journal of Children's Rights 2017 (25(2)), 320-334. Dor: 10.1163/15718182-02502003.

Charles, A. and Haines, K., "Measuring Young People's Participation in Decision Making", The International Journal of Children's Rights, 2014 (22(3)), 641-659. DoI: 10.1163/15718182-55680022.

Child Rights Now!, A second revolution: https://child-rights-now.org/ (14.9.19).

Clarkin-Phillips, J. and Carr, M., "An affordance network for engagement", European Early Childhood Education Research Journal 2012 (20(2)), 177-187. DoI:10.1080/13502 93X.2012.681130. 
Collins, T.M., “The Relationship between Children's Rights and Business”, The International Journal of Children's Rights 2014 (18(6)), 582-633. DOI:10.1080/13642987.2014 .944805 .

Cook, D.T., "Taking exception with the child consumer", Childhood 2013 (20(4)), 423428. DOI: $10.1177 / 0907568213501858$.

Cook, P., "Understanding the Effects of Adolescent Participation in Health Programmes", The International Journal of Children s Rights 2008 (16(1)), 121-139. DOI: 10.1163/092755608X267139.

Crowley, A., "Is Anyone Listening - The Impact of Children's Participation on Public Policy", The International Journal of Children s Rights 2015 (23(3)), 602-621. DOI:10.1163/15718182-02303005.

Cuevas-Parra, P. and Tisdall, E.K.M., “Child-Led Research”, Social Sciences 2019 (8(2)), 44. DOI:10.3390/socsci8020044.

Daly, A., "No Weight for 'Due Weight'? A Children's Autonomy Principle in Best Interest Proceedings", The International Journal of Children's Rights 2018 (26(1)), 61-92. 10.1163/15718182-02601012.

Davis, J., "Analyzing Participation and Social Exclusion with Children and Young People Lessons from Practice", The International Journal of Children's Rights 2007 (15(1)), 121-146. DoI:10.1163/og2755607X181702.

Department of Children and Youth Affairs Ireland, National Strategy on Children and Young People's Participation in Decision-Making (2015): https://assets.gov.ie/24462/ 48a6f98a921446ad85829585389e57de.pdf (12 November 2019).

Dunst, C.J., Hamby, D., Trivette, C.M., Raab, M. and Bruder, M.B., "Young Children's Participation in Everyday Family and Community Activity", Psychological Reports 2002 (91(3)), 875-897. DOI:10.2466/pro.2002.91.3.875.

Edmonds, R., "Making children's 'agency' visible”, Global Studies of Childhood 2019 (9(2)), 200-211. DOI:10.1177/2043610619860994.

Ensor, M.O. and Reinke, A.J., "African Children's Rights to Participate in Their Own Protection", The International Journal of Children's Rights 2014 (22(1)), 68-92. DoI: 10.1163/15718182-02201003.

Esser, F, Baader, M.S., Betz, T. et al. (eds.), Reconceptualising Agency and Childhood (Abingdon: Routledge, 2016).

Fitzgerald, R., Tamar, M., Graham, A., Bajpai, A. and Taylor, N., "International Models of Child Participation in Family Law Proceedings following Parental Separation/ Divorce",The International Journal of Children's Rights 2012 (20(4)), 645-673. DOI: 10.1163/15718182-55680006.

Forde, C., Martin, S. and Galvin, A.D., "Children and young people's right to participate", The International Journal of Children's Rights 2016 (24(1)), 135-154. DoI:10.1163/ 15718182-02401005. 
Franklin, A. and Sloper, P., "Listening and responding? Children's participation in health care within England", The International Journal of Children's Rights 2005 (13(1-2)), 11-29. DOI:10.1163/1571818054545277.

Gal, T. and Duramy, B.F. (eds.), International Perspectives and Empirical Findings on Child Participation (Oxford: Oxford University Press, 2015).

Gallagher, M., "Foucault, Power and Participation",The International Journal of Children's Rights 2008 (16(3)), 395-406. DoI:10.1163/157181808X311222.

Gallagher, M., "Rethinking children's agency: Power, assemblages, freedom and materiality", Global Studies of Childhood 2019 (9(3)), 188-199. DOI:10.1177/20436106198 60993.

Garland-Thomson, R., "Feminist Disability Studies", Signs 2005 (30(2)), 1557-1587. DOI:10.1086/423352.

Gwandure, C. and Mayekiso, T., "Promoting Children's Public Participation in South Africa”, The International Journal of Children's Rights 2011 (19(2)), 233-250. DOI:10.116 3/157181810X525240.

Hanson, K., Abebe, T., Aitken, S.C., Balagopalan, S. and Punch, S., “Global/local' research on children and childhood in a 'global society', Childhood 2018 (25(3)), 272-296. DOI:10.1177/0907568218779480.

Hart, J., “Children's Participation and International Development”, The International Journal of Children's Rights 2008 (16(3)), 407-418. DoI:10.1163/157181808X311231.

Hart, R., Children's Participation: The Theory and Practice of Involving Young Citizens in Community Development and Environmental Care (London: Earthscan, 1992).

Hester, S. and Moore, S., "Understanding Children's Participation through an Eliasian Lens", The International Journal of Children's Rights 2018 (26(3)), 446-467. DoI: 10.1163/15718182-02603002.

Houghton, C., "Young People's Perspectives on Participatory Ethics", Child Abuse Review 2015 (24(4)), 235-248. DoI:10.1002/car.2407.

Imoh, A. T-D., Bourdillon, M. and Meichsner, S. (eds.), Global Childhoods beyond the North-south Divide (Basingstoke: Palgrave, 2019).

Invernizzi, A. and Milne, B., "Are children entitled to contribute to international policy making? A critical view of children's participation in the international campaign for the elimination of child labour", The International Journal of Children's Rights 2002 (10(4)), 403-431. DOI:10.1163/157181802100380735.

Johnson, V., "Conditions for change for children and young people's participation in evaluation: 'Change-scape”, Child Indicators Research 2011 (4(4)), 577-596. DoI: 10.1007/s12187-010-9099-6.

Johnson, V., "Moving beyond voice in children and young people's participation", Action Research 2017 (15(1)), 104-124. DOI:10.1177/1476750317698025. 
Jones, T., "Unsatisfactory Progress: Article 12 and Pupil Participation in English Schools", The International Journal of Children's Rights 2017 (25(1)), 68-84. DoI:10.1163/ 15718182-02501003.

Kilkelly, U. and Donnelly, M., "Participation in Healthcare”, The International Journal of Children's Rights 2011 (19(1)), 107-125. DOI:10.1163/157181810X522379.

Klocker, N., "An example of thin agency" in Panelli R., Punch S. and Robson E. (eds.), Global Perspectives on Rural Childhood and Youth (London: Routledge, 2007).

Kosher, H., "What Children and Parents Think about Children's Rights to Participation", The International Journal of Children's Rights 2018 (25(2)), 295-328. DoI:10.1163/ 15718182-02602005.

LaFrancois, B.A., "It's Like Mental Torture: Participation and Mental Health Services", The International Journal of Children s Rights 2008 (16(2)), 211-227. DOI:10.1163/15718 $1808 X_{301809 .}$

Larkins, C., Lloyd, J., Thomas, N., Carter, B., Farrelly, N.J. and Judd, D., "Support for Children's Protagonism", The International Journal of Children's Rights 2015 (23(2)), 332364. DOI:10.1163/15718182-02302009.

Larsson, I., Staland-Nyman, C., Svedberg, P., Nygren, J.M., Carlsson, I., "Children and young people's participation in developing interventions in health and well-being", BMCHealth Services Research 2018 (18), 507. D0I:10.1186/s12913-018-3219-2.

Leviner, P., "Child Participation in the Swedish Child Protection System", The International Journal of Children's Rights 2018 (26(1)), 136-158. DOI: 10.1163/15718182 -02601002.

Liebel, M., "Paternalism, Participation and Children's Protagonism", Children, Youth and Environments, 2007 (17(2)), 56-73. DOI:10.7721/chilyoutenvi.17.2.0056.

Liebel, M. and Invernizzi, A., "The Movements of Working Children and the International Labour Organization. A Lesson on Enforced Silence", Children \& Society 2018 (33(2)), 142-153. DOI: 10.1111/chso.12305.

Livingstone, S., "Children's Digital Rights: A priority", Intermedia 2014 (42(4/5)), 20-24. Lundy, L., "In defence of tokenism? Implementing children's rights to participate in collective decision-making”, Childhood 2019 (25(3)), 340-354. DoI:10.1177/09075 68218777292

Lundy, L., "Voice' is not enough: Conceptualising Article 12 of the United Nations Convention on the Rights of the Child", British Educational Research Journal 2007 (33(6)), 927-942, DOI:10.1080/01411920701657033.

Mayall, B., "An afterword: some reflections on a seminar series", Children's Geographies $2012(10(3))$, 347-355. DOI:10.1080/14733285.2012.693383.

Meekison, J. and Wan, S., "A young person's guide to defending human rights", International Journal of Human Rights 2019 (23(3)), 442-446. DOI:10.1080/13642987.2018.155 8991. 
McMellon, C. and Mitchell, M., "Participatory Action Research and Young People" in Ravenscroft J. and Hamilton L. (eds.), Building Research Design in Education (London: Bloomsbury, 2018).

McNamee, S. and Seymour J., "Towards a sociology of 10-12 year olds? Emerging methodological issues in the 'new' social studies of childhood", Childhood 2013 (20(2)), 156-168. DoI:10.1177/0907568212461037.

Moran-Ellis, J. and Tisdall, E.K.M., “The relevance of 'competence' for enhancing or limiting children's participation: unpicking conceptual confusion", Global Studies of Childhood 2019 (9(3)), 212-223. DOI:10.1177/2043610619860995.

Moses S., "Children and Participation in South Africa", The International Journal of Children's Rights 2008 (16(3)), 327-342. Dor:10.1163/157181808X311178.

Mühlbacher, S. and Sutterlüty, F., "The principle of child autonomy", Global Studies of Childhood 2019 (9(3)), 249-26o. DoI:10.1177/204361061986o999.

Nolas, S-M., Carvantakis, C. and Aruldoss, V., “(Im)Possible Conversations? Activism, Childhood and Everyday Life", Journal of Social and Political Psychology 2016 (4(1)), 2195-3325. DOI:10.5964/jspp.v4i1.536.

Nuggehalli, R., "Children and Young People as Protagonists and Adults as Partners" in Westwood J., Larkins C., Moxon, D., Perry Y., Thomas N. (eds.), Participation, Citizenship and Intergenerational Relations in Children and Young People's Lives (10-22) (London: Palgrave Pivot, 2014).

Ochaíta, E. and Espinosa, M.A., "Children's participation in family and social life", The International Journal of Children's Rights 1997 (5(3)), 279-297. DOI:10.1163/157181 89720493690.

Parkinson, P., "The child participation principle in child protection law in New South Wales", The International Journal of Children's Rights 2001 (9(3)), 259-272. DoI: 10.1163/15718180120494964.

Pascal, C. and Bertram, T., "Listening to young citizens: The struggle to make real a participatory paradigm in research with young children", European Early Childhood Education Research Journal 2009 (17(2)), 249-262. DOI: 10.1080/1350293090295 1486.

Percy-Smith, B. and Thomas, N. (eds.), A Handbook of Children and Young People's Participation (London: Routledge, 2010).

Pereznieto, P., Powell, A.G., and Avdagic, M., Investment in children (London: Overseas Development Institute, 2011).

Prout, A. and James, A.," A new paradigm for the sociology of childhood?" in James A. and Prout A. (eds.), Constructing and Reconstructing Childhood (London: The Falmer Press, 1990).

Rampal, A., "Scaffolded Participation of Children", The International Journal of Children's Rights, 2008 (16(3)), 313-325. DoI:10.1163/157181808X311169. 
Rap, S., "A Children's Rights Perspective on the Participation of Juvenile Defendants in the Youth Court", The International Journal of Children's Rights 2016 (24(1)), 93-112. DOI:10.1163/15718182-02303006.

Rizzini, I., “The Promise of Citizenship for Brazilian Children?", Annals of The American Academy of Political and Social Science 2011(633), 66-79. DOI:10.1177/0002716210 383950.

Ruiz-Casares, M., Collins, T.M., Tisdall, E.K.M., and Grover, S., “Children's rights to participation and protection in international development and humanitarian interventions", The International Journal of Human Rights 2017 (21(1)), 1-13, DOI:10.1080/1 3642987.2016.1262520.

Shier, H., "Pathways to Participation: Openings, opportunities and obligations", Children \& Society (2001) (15(2)), 107-117. DoI:10.1002/chi.617.

Shier, H., "Children as researchers in Nicaragua: Children's consultancy to transformative research", Global Studies of Childhood (2015) (5(2)), 206-219. DoI:10.1177/ 2043610615587798.

Sinclair, R., "Participation in practice: making it meaningful, effective and sustainable," Children \& Society 2004 (18(2)), 106-118. DoI: 10.1002/chi.817.

Smith, A.B., "Children and Young People's Participation Rights in Education", The International Journal of Children's Rights 2007 (15(1)), 147-164. DoI:10.1163/og27556o 7X181739.

Smith, A.B., "Interpreting and Supporting Participation Rights: Contributions from sociocultural theory", The International Journal of Children's Rights 2002(10(1)), 73-88. DOI:10.1163/157181802772758137.

Struthers, A., "Breaking Down Boundaries: Voice and participation in English primary education”, The International Journal of Children's Rights 2016 (24(2)), 434-468. DOI:10.1163/15718182-02402011.

Taylor, M. and Percy-Smith, B., "Children's Participation: Learning from and for Community Development”, The International Journal of Children's Rights 2008 (16(3)), 379-394. DOI:10.1163/157181808x311213.

Taylor, N., "Child Participation: Overcoming disparity between New Zealand's family court and out-of-court dispute resolution processes", The International Journal of Children's Rights 2017 (25(3-4)), 658-671. DoI:10.1163/15718182-02503004.

Taylor, N., Tapp, P. and Henaghan, M., "Respecting children's participation in family law proceedings", The International Journal of Children's Rights 2007 (15(1)), 61-82. DoI:1 0.1163/092755607X185555.

Theobald, M., Danby, S. and Ailwood, J., "Child Participation in the Early Years: Challenges for Education", Australasian Journal of Early Childhood 2011 (36(3)), 19-26. DOI:10.1177/183693911103600304.

Thomas, N., "Towards a theory of children's participation", The International Journal of Children's Rights 2007 (15(2)), 199-218. DoI:10.1163/o92755607X206489. 
Tisdall, E.K.M., "Children and Young People's Participation” in Vandenhole W., Desmet E., Reynaert D. and Lembrechts S. (eds.), Routledge International Handbook of Children's Rights Studies (Abingdon: Routledge, 2015).

Tisdall, E.K.M. and Cuevas-Parra, P., “Challenges for children's participation: child activism for ending child marriage”, 2019, DOI:10.1016/j.childyouth.2019.104568.

Tisdall, E.K.M., Hinton, R., Gadda, A.M. and Butler, U.M., "Introduction: Children and Young People's Participation in Collective Decision-Making”, in Tisdall E.K.M., Gadda A.M., and Butler U.M. (eds.), Children and Young People's Participation and Its Transformative Potential (Basingstoke: Palgrave Macmillan, 2014).

Tisdall, E.K.M. and Punch, S., "Not so 'new'? Looking critically at Childhood Studies", Children's Geographies 2012 (10(3)), 249-264. DOI:10.1080/14733285.2012.69 3376.

Tisdall, E.K.M., "Is the Honeymoon Over? Children and Young People's Participation in Public Decision-Making”, The International Journal of Children s Rights 2008 (16(3)), 419-429. DOI:10.1163/157181808X311240.

Tisdall, E.K.M., "Meaningful, effective and sustainable? Challenges for children and young people's participation“, in Bruselius-Jensen M., Pitti I., and Kay E.Tisdall M. (eds.), Young People's Participation (Bristol: Policy Press, forthcoming).

Tomanović-Mihajlović, S., "Young People's Participation within the Family", The International Journal of Children's Rights 2000 (8(2)), 151-167. DoI:10.1163/157181800 20494569.

Treseder, P., Empowering children and young people training manual: promoting involvement in decision-making (London: Save the Children, UK, 1997).

UN Committee on the Rights of the Child, General Comment No. 5, General measures of implementation of the Convention on the Rights of the Child, 2003: http://tbinternet .ohchr.org/_layouts/treatybodyexternal/Download.aspx?symbolno=CRC\%2fGC\% 2f $2003 \% 2 f 5 \&$ Lang=en (27.5.14).

UN Committee on the Rights of the Child, General Comment No. 12, The Right of the Child to be Heard, 2009: https://www2.ohchr.org/english/bodies/crc/docs/Advance Versions/CRC-C-GC-12.pdf (30 May 2019).

Valentin, K. and Meinert, L., "The Adult North and the Young South", Anthropology Today 2009 (25(3)), 23-28. DoI:10.1111/j.1467-8322.2009.00669.x.

Vanner, C., "We Are the Assets of the School: Children's Participation Rights in a School Health and Nutrition Project in El Salvador", The International Journal of Children's Rights 2014 (22(2)), DOI:10.1163/15718182-02202005.

von Benzon, N. and van Blerk, L, "Research relationships and responsibilities: 'Doing' research with 'vulnerable' participants”, Social \& Cultural Geography 2017 (18(7)), 895-905. DOI: 10.1080/14649365.2017.1346199.

van Bijleveld, G.G., Dedding, C.W.M. and Bunders-Aelen, J.F.G., "Children's and young people's participation within child welfare and child protection services: A 
state-of-the-art review", Child \& Family Social Work 2015 (20(20)), 129-138. DoI: $10.1111 /$ cfs.12082.

Wall, J. and Dar, A., "Children's Political Representation: The right to make a difference", International Journal of Children's Rights 2011 (19(4)), 595-612. DOI: 10.1163/15718 $1811 X_{547263 .}$

Wells, K., Childhood in a Global Perspective ( $2^{\text {nd }}$ edn.) (Cambridge: Polity Press, 2015).

Wheeler, A., "Children's Participation in Educational Projects and Sustainable Design", The International Journal of Children's Rights 2010 (18(3)), 457-474. DOI:10.1163/15718 1810 X497297.

Winter, K., "The Participation Rights of Looked after Children in Their Health Care", The International Journal of Children's Rights 2006 (14(1)), 77-95. D OI:10.1163/157181 806776614354 .

World Vision, Leading the Way: Guidance on the participation of children and young people in global engagements: https://www.wvi.org/sites/default/files/WV-Leading -the-Way-2017-04-11.pdf (12 November 2019).

Wyn, J., “Generation and Class: Young People's New, Diverse Patterns of Life and Their Implications for Recognising Participation in Civic Society", The International Journal of Children's Rights 2007 (15(1)), 165-179. DoI:10.1163/o92755607X181757.

Wyness, M., "Children, Childhood and Political Participation", The International Journal of Children's Rights 2001 (9(3)), 193-212. DOI:10.1163/15718180120494937. 